\title{
Vigilance in reindeer (Rangifer tarandus); evolutionary history, predation and human interference
}

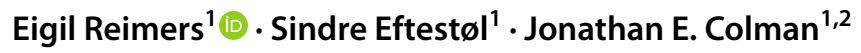

Received: 17 September 2020 / Revised: 24 March 2021 / Accepted: 26 March 2021 / Published online: 11 April 2021

(c) The Author(s) 2021

\begin{abstract}
To elucidate genetic variability in vigilance behaviour for reindeer with historical differences in their interactions with predators and humans, we measured vigilance frequency and duration for grazing reindeer in Southern Norway (Rondane and Norefjell-Reinsjøfjell), Svalbard (Edgeøya and Nordenskiöld Land) and Barf/Royal Bay and Busen in the southern Hemisphere (South Georgia). Averaged for all areas, frequency and duration of vigilance bouts were less than 0.5 and $2.5 \mathrm{~s}$, respectively. Frequency was insignificantly 1.3 times higher in Rondane than Edgeøya, and significantly 2.0, 3.5, 5.2 and 12.4 times higher than Norefjell, Nordenskiöld Land, Barf/Royal Bay and Busen, respectively. Duration per vigilance bout was not different amongst the areas. Thus, while frequency varied considerably, duration remained constant, supporting a hard-wired adaptation to, among other suggestions, an open landscape. Plasticity in frequency allows for flexible behavioral responses to environmental factors with predation, domestication and hunting key drivers for reindeer. Other factors include (1) the open, treeless alpine/Arctic environment inhabited by Rangifer subspecies allowing warning time, (2) grouping behaviour, (3) relative low density of predators and (4) the anatomy and physiology of ungulate vision.
\end{abstract}

Keywords Watchfulness · Isolation on islands · Predation · Domestication · Ungulates $\cdot$ Reindeer $\cdot$ Rangifer tarandus

\section{Introduction}

Behavioural traits in animals certainly evolve, and the domestication of animals was essential for the development of modern human societies. Genetically based behavioural traits vary amongst animals. Early man utilized this variability to select species that served their needs for protection and hunting (dogs), as well as a wide variety of food and clothing purposes. Selection towards domestication supported tameness for improved handling and maintenance of livestock (Price 1984), while pre-modern hunting likely selected for traits increasing a species survival abilities through increased fright, flight and vigilance behaviours. Interestingly, knowledge about changes in behavioural traits related to wildness and tameness is lacking, often due to

Eigil Reimers

eigil.reimers@ibv.uio.no

1 Institute of Biosciences, Blindern, University of Oslo, P.O. Box 1066, 0316 Oslo, Norway

2 Faculty of Environmental Sciences and Natural Resource Management, Norwegian University of Life Sciences, P.O. Box 5003, 1432 Ås, Norway extinction of the wild parent stock (Clutton-Brock 1987). There is limited experimental research on the evolution of different traits, including behaviour, during domestication. However, there is some evidence based on comparative studies of domestic stocks and their wild ancestors to identify a number of typical domestication changes, including the following aspects (Jensen 2006): external and internal morphology, physiology, body development and behaviour, which in this context includes reduced fear, increased sociability, and reduced anti-predator responses (Price 1997). Interestingly, this complex of changes may develop rapidly, in only a few generations, and in concert, even though only one of the traits is selected for (Jensen 2014). As with many traits, there can be variation in the amount of plasticity of expression in behavior traits involving the discovery and avoidance of predators.

While domestication tends to relax anti-predator behaviour, such as vigilance, predation tends to increase it (Reimers et al. 2012). Thus, in addition to domestication, local extinction of predators for prolonged periods should theoretically relax natural selection on predator recognition and other behavior responses, such as grouping. Over $100 \mathrm{~s}$ or $1000 \mathrm{~s}$ of years, prey may lose the ability to recognize 
locally extinct predators as dangerous (Coss 1999; Berger et al. 2001; Blumstein and Daniel 2005a; Blumstein 2006; Stankowich and Coss 2007; Lahti et al. 2009). Reindeer (Rangifer tarandus) present an interesting species because they inhabit areas with variable amounts of predation and hunting. Reindeer were only recently domesticated by humans, with extensive control of specific herds first evolving during the 16th and 17th centuries (Mirov 1945). Almost $50 \%$ of the approximate 3 million reindeer in the Old World are wild animals, and wild and domestic herds are managed in close coexistence (Reimers and Klein 1979; Baskin 2005). Reindeer in some areas exhibit variable amounts of grouping behavior and interactions with predators exemplified by Svalbard reindeer, as we present below.

The multi-predator hypothesis (Blumstein 2006) promotes that isolation from all predators may lead to a rapid loss of antipredator behaviour, including loss of the grouping behaviour and breakdown of predator recognition abilities. For example, both reindeer and caribou from regions without wolves (Svalbard and West Greenland) exhibited about a third of the vigilance towards playbacks of wolf howling at control sites (Denali National Park and Tetlin Wildlife Refuge) (Berger 2007).

Experience-dependent behavior, such as vigilance and fright and flight, may be moderated or lost after few generations in the absence of predators, while more "hard-wired" antipredator behavior, such as forming groups, may persist for $1000 \mathrm{~s}$ of years following isolation from predators (Byers 1997; Coss 1999). On the other hand, experience-dependent behaviour may be quickly restored the first time individuals encounter predators (Brown et al. 1997; Aastrup 2000; Berger et al. 2001), contrary to hard-wired behavior. In accordance with this, vigilance rates (frequency of "scans" per time interval) (Bøving and Post 1997; Frid 1997), displayed by Svalbard reindeer in Edgeøya, a location with a dense polar bear population, were 2.2 times higher than those for reindeer in Nordenskiöld Land that had fewer polar bears (Reimers et al. 2011). Furthermore, and in accordance with a hard-wired trait, reindeer in both areas remain alone or in small groups; i.e., they lack grouping behaviour in these two areas as well as in all other reindeer-inhabited areas on Svalbard.

Ungulates periodically scan their surroundings for potential threats that might be looming. This behaviour may be shared by members of a group, which would likely be more proficient at scanning than a solitary animal that must divide its time between scanning and other activities (e.g., foraging). Thus, there is likely an interaction between the experience-dependent vigilance rate and hard-wired grouping behaviours, with a decrease in vigilance rate with an increase in grouping. Grazing ungulates in groups or herds may also scan their surroundings in search of feeding hot spots or social cues relating to other intra and inter specific interactions (Colman et al. 2012) that likely acts in synergy with predatory vigilance.

While vigilance rate seemingly varies (Reimers et al. 2012), we are less certain of whether the time an animal scans its surroundings per vigilance bout, vigilance duration, also varies. Grouping behaviour is widespread among mammals living in open landscapes, is most conspicuous among larger herbivores and primarily influenced by resource availability and distribution (Matthiopoulos 2003), parasites (biting flies, warble flies and parasitoids) (Mooring et al. 2004), and predator pressure (Hamilton 1971). Temporary or permanent aggregations commonly formed by mammals have a variety of potential benefits; enhanced vigilance through more scanning eyes, greater ability to find food or mates, group defense, confuse predators, and decreased probability to get killed during a predator attack (dilution effect). There are also potential costs; easier to locate by predators, potential for disease transmission, interference effects during foraging, and negative interaction with other animals. Declining individual vigilance rates with increasing group size has indeed been widely reported for both mammals and birds (Elgar 1989; Lima 1995), although other influential factors than predators and insects [e.g., nutrition and competitors (Colman et al. 2012)] may interfere. The duration of a vigilance bout in conjuncture with vigilant rate determines the extent of potential trade-offs. However, it remains unknown whether vigilance duration varies in a manner similar to rates. We aimed therefor to test and compare variation in both vigilance rate and duration for populations differing in other ways (grouping behaviour and interactions with humans and predators) as a starting point into whether these traits are hard-wired or experience based.

Wild reindeer in southern Norway conform to the grouping strategy in terms of vigilance and fright and flight behaviour (Reimers et al. 2012). Antipredator grouping behaviour should not persist on islands without predation if there is no net benefit (Blumstein and Daniel 2005a). Following this, the traditional grouping behaviour that characterizes Rangifer elsewhere (Reimers et al. 2011, 2012) is absent on Svalbard, where animals live individually or in small groups with limited predation for 1000s of years (Van der Knaap 1986).

In this study, we compare vigilance behavior for two reindeer herds in southern Norway, two herds in Svalbard and two herds, now exterminated, in South Georgia. All 6 areas are different in relation to predator presence and /or human influence through hunting and/or domestication. Based upon the presented extensive vigilance data, we hypothesize that in Rangifer, duration of individual vigilance bouts are genetically hard wired, while frequency of vigilance bouts and duration of vigilance per minute grazing are experiencebased. We also relate the theorized experience-based vigilance rate behavior to the hard-wired grouping behavior, and include vigilance duration to test its variability. 


\section{Study areas}

We collected data on vigilance between July and August 2006 for Edgeøya and Nordenskiöld Land, 5150 and 39,000 $\mathrm{km}^{2}$, respectively (Svalbard, $74^{\circ}-81^{\circ} \mathrm{N}$ ), between June and July in the years 2004 to 2006 for Rondane and NorefjellReinsjøfjell, 1441 and $308 \mathrm{~km}^{2}$, respectively (Southern
Norway, $60^{\circ}-63^{\circ} \mathrm{N}$ ) (Reimers et al. 2012), and betweenDecember and January (corresponding to June/July on the southern Hemisphere) in the year 2012 to 2013 for Barf/ Royal Bay and Busen, 124 and $131 \mathrm{~km}^{2}$, respectively (South Georgia, $53^{\circ}-55^{\circ} \mathrm{S}$ ) (Fig. 1 and Table 1). A detailed description of reindeer herds and ranges in southern Norway and Svalbard follows from Reimers et al. (2012), Reimers et al.

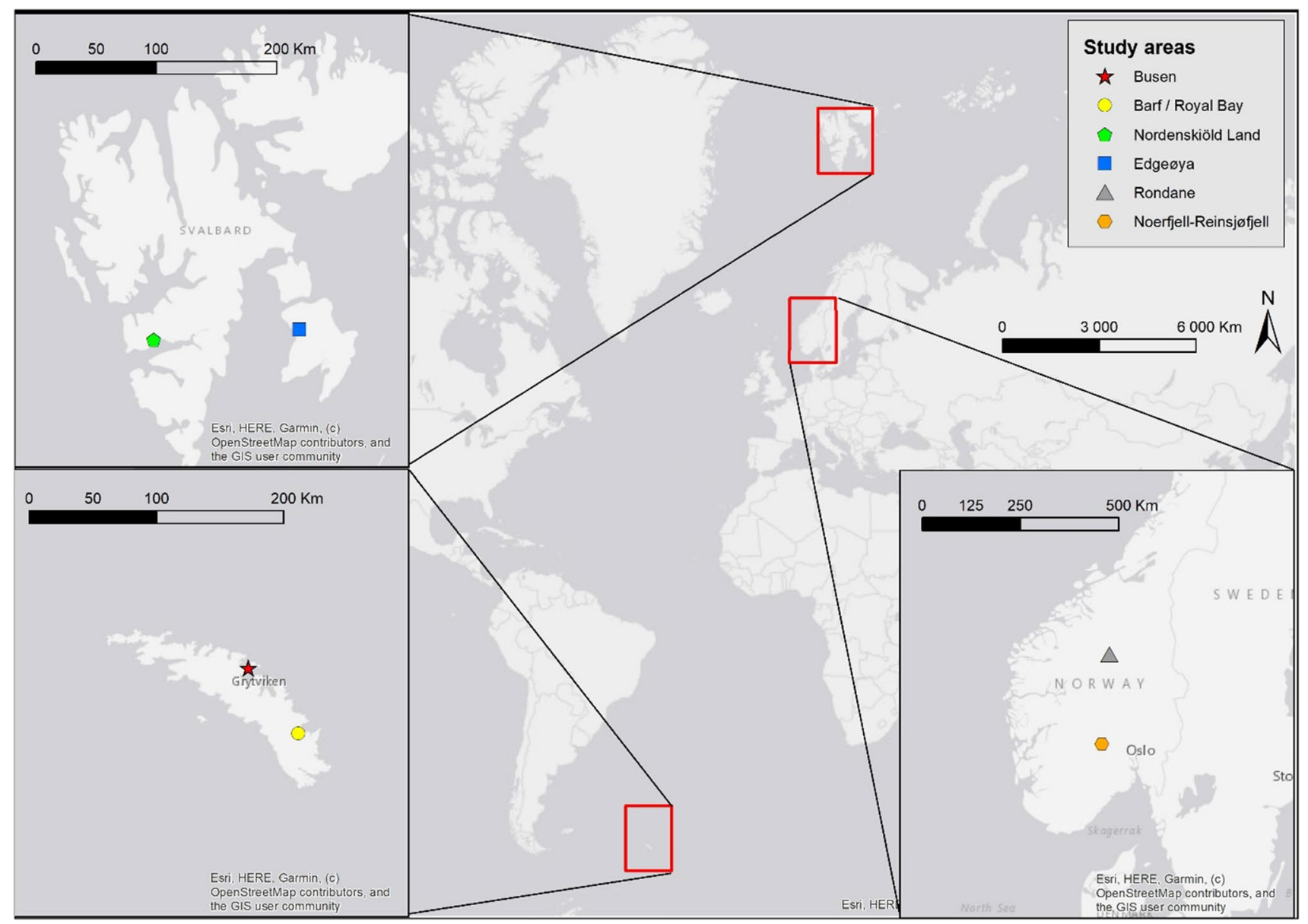

Fig. 1 Location of the various reindeer herds indicated by their latitudinal and longitudinal positions: Svalbard: $77^{\circ} 39^{\prime} \mathrm{N}, 2^{\circ} 29^{\prime} \mathrm{E}$; Southern Norway: $62^{\circ} 15^{\prime} \mathrm{N}, 09^{\circ} 33^{\prime} \mathrm{E}$ and South Georgia: $54^{\circ} 16^{\prime} \mathrm{S}, 54^{\circ} 16^{\prime} \mathrm{W}$

Table 1 Distribution of animal's video recorded in the areas, average scan duration, area size inhabited by video-scanned reindeer, animal density and average group size of video recorded reindeer

\begin{tabular}{|c|c|c|c|c|c|c|}
\hline Area & Sub-area & $\begin{array}{l}\text { No of video- } \\
\text { recorded animals }\end{array}$ & $\begin{array}{l}\text { Average scan } \\
\text { duration (s) }\end{array}$ & Area size $\left(\mathrm{km}^{2}\right)$ & Animals $/ \mathrm{km}^{2}$ & $\begin{array}{l}\text { Average } \\
\text { group size } \\
( \pm S E)\end{array}$ \\
\hline \multirow[t]{2}{*}{ Southern Norway } & Rondane & 260 & 181 & 1441 & 1.0 & $555 \pm 23.1$ \\
\hline & Norefjell & 333 & 223 & 308 & 1.5 & $92 \pm 4.1$ \\
\hline \multirow[t]{2}{*}{ Svalbard } & N.Land & 216 & 540 & 798 & 3.2 & $2.4 \pm 0.12$ \\
\hline & Edgeøya & 174 & 432 & 120 & 1.5 & $2.2 \pm 0.12$ \\
\hline \multirow[t]{2}{*}{ South Georgia } & Barf/Royal Bay & 325 & 349 & 189 & 25.1 & $50 \pm 2.8$ \\
\hline & Busen & 170 & 449 & 124 & 16.2 & $50 \pm 3.9$ \\
\hline
\end{tabular}


(2011) and correspondingly for South Georgia, from Leader Williams (1988).

Areas in southern Norway are mainly alpine terrain at altitudes of 1000-1500 m. Hunting is allowed in all areas and is the only important mortality factor, as wolves (Canis lupus L.) are essentially absent from the areas and wolverine (Gulo gulo L.), golden eagle (Aquila chrysaetos L.) and lynx (Lynx lynx L.), although permanently present or present as stragglers, exert minor predatory influence. Rondane reindeer are considered to be mainly of wild origin due to their distinct genetic variation when compared with domestic reindeer (Røed 1985, 1987; Røed et al. 2008). The Norefjell-Reinsjøfjell herd originated from some 30 reindeer that escaped slaughter in 1968 when the reindeer herding company closed (Reimers et al. 2009). Norefjell-Reinsjøfjell reindeer are genetically distinctly different from neighboring wild reindeer herds (Andersen and Hustad 2004; Reimers et al. 2012).

Despite the high latitude, the climate in Svalbard is relatively mild due to the North-Atlantic Current. The landscape is mountainous with peaks up to $1700 \mathrm{~m}$. Large areas are covered by glaciers, and summer pastures for reindeer are restricted to valleys, coastal plains and plateaus. Hunting of Svalbard reindeer was banned in 1925 when Norway was assigned sovereignty of Svalbard. Since then, reindeer densities have increased, which led to the reopening of limited hunting on Nordenskiöld Land in 1983. Comprising the northernmost populations of Rangifer, the insular Svalbard reindeer (Rangifer tarandus platyrhynchus) inhabit an environment without grazing competitors or parasitizing insects. Besides polar bears (Ursus maritimus), which occasionally prey on Svalbard reindeer (Derocher et al. 2000; Sandal 2008; Hovelsrud 2009), and Arctic fox (Vulpes lagopus), which kill a few newborn calves (Tyler 1986), there are no other predators that are part of the natural habitat of reindeer elsewhere. This situation has prevailed for at least 4000 years (Van der Knaap 1986; Tyler and Øritsland 1989). Contrary to Rangifer subspecies elsewhere, Svalbard reindeer live individually or in small groups (Alendal and Byrkjedal 1976; Alendal et al. 1979), are seasonally sedentary (Tyler and Øritsland 1989) and are not nomadic.

Norwegian domestic reindeer were introduced by whalers to the Barf Peninsula on South Georgia in 1911 (10 animals; 3 males and 7 females) (Olstad 1930). A second group (7 animals; 3 males and 4 females) was introduced to the Busen area in 1926 (Olstad 1930; Leader Williams 1988) (Table 2). Both introductions used animals from Filefjell domestic reindeer company in southern Norway (Lovatt 2007; Kilander 2014). The reindeer have been free ranging since their introduction and were protected under the Falkland Island Dependencies Conservation Ordinance of 1975. Permits were issued to shoot reindeer for consumption by personnel at the scientific station at Grytviken, and for scientific programs. Derived from the Barf herd during 1961-1965, an unknown number of reindeer spread around a retreating glacier snout which had previously formed a restriction boundary making a new herd: The Royal Bay herd (Table 2) (Leader Williams and Payne 1980; Lindsey 1973). While the Busen area has a small permanent human settlement, the Barf/Royal Bay area is isolated and rarely visited by humans. Due to this, only the reindeer herd in Busen were exposed to poaching/hunting (until their protection in 1975). None of the reindeer herds in South Georgia are affected by predators (Leader Williams 1988).

Because of concerns over the impact on the native vegetation, including over-grazing, soil erosion, loss of biodiversity in the plant communities and increased distribution of introduced plant species and rodents, the phased eradication of reindeer from South Georgia became policy of the SGSSI in 2000 (McIntosh and Walton 2000). Extermination of the herds occurred during 2012-2014, resulting in 6749 animals killed; approximately twice the number of animals estimated to live on the island. Apparently, only a few animals survived the extermination and were left to the British authorities to remove.

Table 2 History of the reindeer herd introduced to South Georgia, harvest and herd development

\begin{tabular}{lclllll}
\hline Reindeer Herd & Area size $\left(\mathrm{km}^{2}\right)$ & Year of Introduction & $\begin{array}{l}\text { No reindeer } \\
\text { introduced }\end{array}$ & $\begin{array}{l}\text { Estimated no rein- } \\
\text { deer in 1976 }\end{array}$ & $\begin{array}{l}\text { No reindeer culled } \\
\text { in 1972-1976 }\end{array}$ & $\begin{array}{l}\text { No reindeer } \\
\text { culled } \\
\text { 2 in } \\
2013-2015\end{array}$ \\
\hline Barf & 131 & 1911 & 10 & 1000 & 370 & 4740 \\
Royal Bay & 58 & $1961-1965$ & $?$ & 550 & 100 & \\
Busen & 124 & 1926 & 7 & 450 & 120 & 2009 \\
Total & 313 & & 17 & 2000 & 590 & 6749 \\
\hline
\end{tabular}

With the exception of 1972/1976 harvest have not exceeded 30 reindeer per year since closure of the whaling stations in 1964-1965 (Leader Williams and Payne 1980)

${ }^{\mathrm{a}}$ Culled in a research program

${ }^{\mathrm{b}}$ Culled in an extermination program 


\section{Material and methods}

Field work in Rondane and Norefjell (southern Norway), Edgeøya and Nordenskiöld Land (Svalbard) was conducted in June/July during 2003-2006 and Barf/Royal Bay and Busen (South Georgia) December-January in 2012 and 2013. We video recorded grazing animals from a hidden position and defined grazing as the act of ingesting forage with the muzzle down. The hidden position was usually several $100 \mathrm{~m}$ from the closest reindeer and varied according to, for example, topography, wind direction, movements of the reindeer and visibility. If there was any suspicion of being discovered, the recordings were terminated. Animals were randomly selected for video recording from different groups in the six areas. We recorded a total of 1478 reindeer 1 year or older combined for the six areas (Table 1). Each individual was recorded preferably for $10 \mathrm{~min}$ (in some cases longer than $10 \mathrm{~min}$ ) or until the reindeer lied down or moved out of sight. We defined a vigilance bout as the act of interrupting feeding to lift the head above the shoulders (Frid 1997) and observe the surroundings for $\leq 10 \mathrm{~s}$ before returning to feeding (Bøving and Post 1997). If this change of behavior lasted more than $10 \mathrm{~s}$, frequently resulting in non-vigilance behaviour like scratching, urinating, and licking before returning to grazing or moving on to another grazing spot, it was disregarded as a vigilance bout. Individuals were scanned only once on the same day.

While filming, the team registered group size, group structure (males, females and yearlings, mixed sex and age of the video recorded animal: lactating female with calf at heel, barren female and male, wind speed following the Beaufort Wind Scale (calm, $<1 \mathrm{~m} \mathrm{~s}^{-1}$; light/gentle breeze, $1.6-5.4 \mathrm{~m} \mathrm{~s}^{-1}$; moderate/fresh breeze, $5.5-10.7 \mathrm{~m} \mathrm{~s}^{-1}$ or gale, $10.8-17.1 \mathrm{~m} \mathrm{~s}^{-1}$ ), weather (sunny/partly sunny, cloudy, rain/snow or foggy) and topography of the surrounding area (i.e., level or rugged). Senior author played back the videotapes on a 27 " plasma TV-monitor following individual reindeer grazing throughout the observation period and registered the number and duration of vigilance bouts. Slow walking between vegetation hot spots with head down was included in total grazing time. Slow walking with head up was excluded from total grazing time.

To assess variation in the frequencies of vigilance bouts, vigilance rate, among main areas and subareas, we fitted the observed vigilance rate data to a Poisson model (Reimers et al. 2011). Assuming that the expected number of vigilance bouts observed for an individual was proportional to the time it was observed, we included $\ln$ (time observed) as a fixed offset in the log-linear model vigilance rate. As the areas and groups were not surveyed on the same days, we included the random variation among days and individuals within groups and days as variance components in the model to account for weather effects and to facilitate robust inferences about the differences among the areas. Hence, we assumed number of vigilance bouts for an individual $i$ observed over $\tau_{i}$ seconds during day $d(i)$ to be Poisson distributed with the log-linear expectation

$\ln \left(\lambda_{\mathrm{i}}\right)=x_{\mathrm{i}} \beta+\ln \left(\tau_{\mathrm{i}}\right)+\delta_{\mathrm{d}(\mathrm{i})}$,

where $\delta_{d(i)}$ is normally distributed, $\delta_{d(i)} \sim N\left(0, \sigma^{2}\right)$, and $x_{\mathrm{i}} \beta$ models the difference between the areas and log-linear effects of covariates $\left(x_{\mathrm{i}}\right)$. This model was fitted with the function 'Imer' in the 'Ime4' package in R version 3.4.3 (http://www.r-project.org/).

Besides effects of area, we evaluated the effect of group size. Groups were smaller in Svalbard than in southern Norway and South Georgia. Hence, group size categories were small: $<5$ animals, medium: $6-8$ animals, and large: $>8$ animals in Svalbard, small: $<20$ animals, medium: $20-50$ animals, and large: $>50$ animals in southern Norway and in South Georgia. Furthermore, we evaluated the effect of group structure (mixed sex groups or single sex groups of either females or males), functional category of the observed animal (lactating female, barren female or male), weather, wind force and wind direction relative to observer.

To compare the mean duration of the vigilance bouts among areas and groups of individuals, a log-normal linear model (including all the fixed and random variables in the model above) was fitted to the duration of the first observed vigilance bout per individual (Fig. 3). Inspection of the residuals showed that the model fitted well to the data. To facilitate interpretation of time spent vigilant while grazing, vigilance duration, in the 6 areas, we multiplied vigilance duration of the first vigilance bout (Fig. 3) with the vigilance rates (Fig. 4a) for presentation in Fig. 4b.

\section{Results}

Observation periods per animal averaged from 181 to $540 \mathrm{~s}$ in the six areas, with the shortest time span in Rondane. Density (reindeer $/ \mathrm{km}^{2}$ ) varied from 1 in Rondane to an all-time high of 25.1 in Barf/Royal Bay, South Georgia (Table 1; Fig. 1).

The vigilance rate among reindeer in South Georgia was, although very low in both areas, three times higher and lasted in total time three times longer among reindeer in Barf than in Busen (Table 3; Fig. 2a, b). Vigilance rate was not influenced by sex of animals, weather conditions, wind force, wind direction or group structure. Vigilance rate and duration decreased with increasing group size (Fig. 2a, 
Table 3 Generalized Linear Model for predicting number of vigilance bouts per min (ln transformed) during grazing in reindeer in Barf/ Royal Bay and Busen (South Georgia) during summer in the southern Hemisphere (December-January) in 2012 and 2013

\begin{tabular}{lrlrr}
\hline Variable & Estimate & $S E$ & z-value & $\operatorname{Pr}(>|z|)$ \\
\hline (Intercept) & -3.3688 & 0.24 & -14.035 & $<0.0001$ \\
$\begin{array}{l}\text { Area: Busen vs. Barf/ } \\
\quad \text { Royal Bay }\end{array}$ & -1.1207 & 0.2442 & -4.589 & $<0.0001$ \\
$\begin{array}{l}\text { Group size: medium vs. } \\
\quad \text { large }\end{array}$ & -0.5451 & 0.2842 & -1.918 & 0.055 \\
$\quad$\begin{tabular}{l} 
Group size: small vs. large \\
\hline
\end{tabular} & 0.9615 & 0.2391 & 4.021 & $<0.0001$ \\
\hline
\end{tabular}

The standard deviation of $\ln$ (number of vigilance bouts per min) among individuals within groups (random intercepts) were estimated at 0.389 and 0.152 , respectively. The full model included area, group size (small $<20$ animals; medium $20-50$ animals; large $>50$ animals), group structure (mixed; females; males), sex of the video recorded animal, weather, wind force and topography. Reference levels for categorical variables are provided in the table (the level after "vs.")
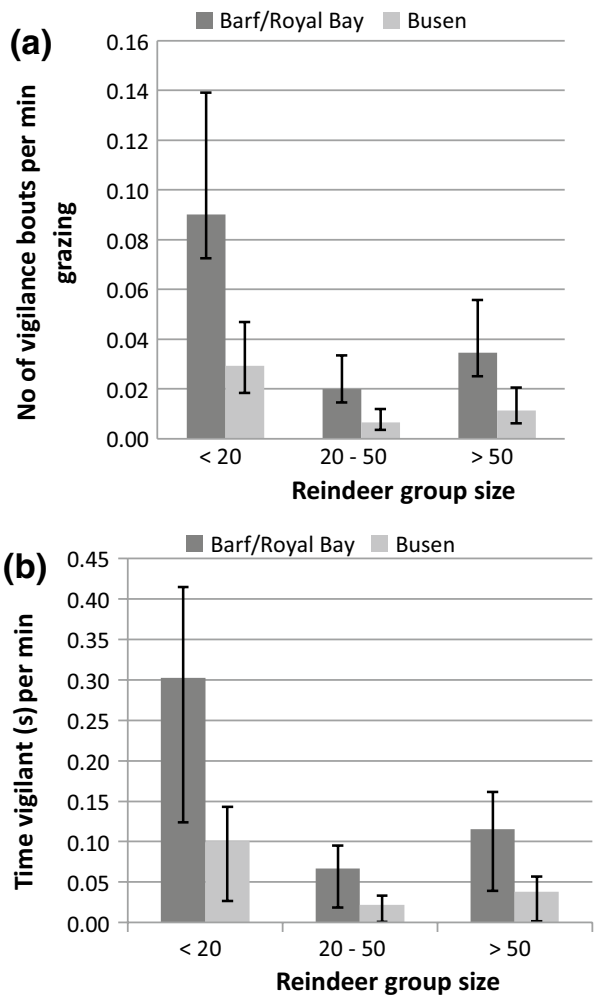

Fig. 2 a Predicted number of vigilance bouts $( \pm 2 S E$; approx. $95 \%$ $C I)$ per min (vigilance rate) with head above shoulder height $\leq 10 \mathrm{~s}$ while grazing in groups of reindeer in Barf/Royal Bay and Busen, (South Georgia) during summer in the southern Hemisphere (December-January) in 2012 and 2013. b Calculated total time spent vigilant (s) per min grazing ( $\pm 2 S E$; approx. $95 \% C I$ ) in reindeer in Barf/ Royal Bay and Busen, South Georgia during summer in the southern Hemisphere (December-January) in 2012 and 2013. Values are products of number of vigilance bouts per min grazing time $\times$ mean duration of first observed vigilance bout in the respective herd size categories. Reference level for categorical variables are rugged area for vigilance duration and group size for vigilance frequency for product values b). Animals in small groups ( $<20$ animals) were 2.6 times more vigilant than animals in large groups ( $>50$ animals).

We compared vigilance data from Barf/Royal Bay and Busen with data from southern Norway and Svalbard (Table 4; Fig. 4a). Vigilance rate was insignificantly 1.3 times higher in Rondane than in Edgeøya and significantly 2.0, 3.5, 5.2 and 12.4 times higher compared with Norefjell, Nordenskiöld Land, Barf/Royal Bay and Busen, respectively. Vigilance rate was not influenced by wind force, wind direction or group structure and decreased with increasing group size. Animals in small groups were 1.8 times more vigilant than animals in large groups and females were 1.3 times more vigilant than males. Finally, animals were 1.4 times more vigilant on sunny days than in overcast weather (Table 4).

Vigilance duration of first vigilance bout (among all individual reindeer observed) was similar, although Rondane reindeer tended to have somewhat shorter duration than animals in Norefjell and Nordenskiöld Land (Table 5; Fig. 3). Although low in all areas, vigilance frequency per minute grazing was 2.9, 1.2, 1.7, 4.7 and 10.7 times longer in Rondane vs. Norefjell, Edgeøya, Nordenskiöls Land, Barf/Royal Bay and Busen, respectively (Fig. 4a). Vigilance duration (duration of first bout multiplied with frequency rate) tended to be longer for female vs. males in small groups (Fig. 4b),

Table 4 Generalized Linear Model for predicting number of vigilance bouts per min (ln transformed) during grazing in reindeer in Rondane and Norefjell in southern Norway, Edgeøya and Nordenskiöld Land in Svalbard and in Barf/Royal Bay and Busen in South Georgia

\begin{tabular}{lrlrr}
\hline Variable & Estimate & $S E$ & $z$-value & $\operatorname{Pr}(>|z|)$ \\
\hline Intercept) & -1.5196 & 0.1045 & -14.540 & $<0.0001$ \\
Edgeøya vs. Rondane & -0.2255 & 0.1539 & -1.465 & 0.1429 \\
$\quad$ Norefjell vs. Rondane & -0.7022 & 0.1362 & -5.155 & $<0.0001$ \\
$\quad$ Nordenskiöld Land vs. & -1.2597 & 0.1544 & -8.158 & $<0.0001$ \\
$\quad$ Rondane & & & & \\
$\quad \begin{array}{l}\text { South Georgia vs. Ron- } \\
\quad \text { dane }\end{array}$ & -1.9687 & 0.1410 & -13.963 & $<0.0001$ \\
$\quad$ Group size: Medium vs. & 0.3839 & 0.1480 & 2.594 & 0.0095 \\
$\quad$ Large & & & & \\
$\quad$ Group size: Medium vs. & 0.5759 & 0.1236 & 4.661 & $<0.0001$ \\
$\quad$ Small & & & & \\
$\quad \begin{array}{l}\text { Sex: Males vs. Females } \\
\quad-0.2824\end{array}$ & 0.0850 & -3.323 & 0.0009 \\
$\quad$ Weather: Sun vs. Overcast & -0.3258 & 0.0816 & -3.9910 & 0.0001 \\
\hline
\end{tabular}

Vigilance was measured in June/July in 2004-2006 in southern Norway and Svalbard and during summer in the southern Hemisphere; December in 2012 and January and December in 2013. The standard deviation of $\ln$ (number of vigilance bouts per min) among individuals within groups (random intercepts) were estimated at 0.073 and 0.277 , respectively. The full model included area, group size (small $<20$ animals; medium 20-50 animals; large $>50$ animals), group structure (mixed; females; males), sex of the video recorded animal, weather, wind force and topography. Reference levels for categorical variables are provided in the table (the level after "vs.") 
Table 5 Calculated duration of first vigilant bout (s) in grazing reindeer in small single sex groups in Rondane and Norefjell (southern Norway), Edgeøya and Nordenskiöld Land (Svalbard) and Barf/Royal Bay and Busen (South Georgia)

\begin{tabular}{llllrr}
\hline Variable & Value & $S E$ & $d f$ & $t$-value & \multicolumn{1}{c}{$p$-value } \\
\hline Intercept & 1.0674 & 0.0599 & 399 & 17.809 & $<0.0001$ \\
Edgeøya vs. Rondane & 0.0738 & 0.0846 & 399 & 0.873 & 0.3832 \\
Nordenskiöld Land vs. Rondane & 0.1922 & 0.0847 & 399 & 2.269 & 0.0238 \\
Norefjell vs. Rondane & 0.1662 & 0.0832 & 399 & 1.997 & 0.0465 \\
Barf/Royal Bay vs. Rondane & 0.1073 & 0.0955 & 399 & 1.124 & 0.2616 \\
Busen vs. Rondane & 0.1269 & 0.1486 & 399 & 0.853 & 0.3939 \\
Males vs. Females & 0.1574 & 0.0666 & 399 & 2.363 & 0.0186 \\
\hline
\end{tabular}

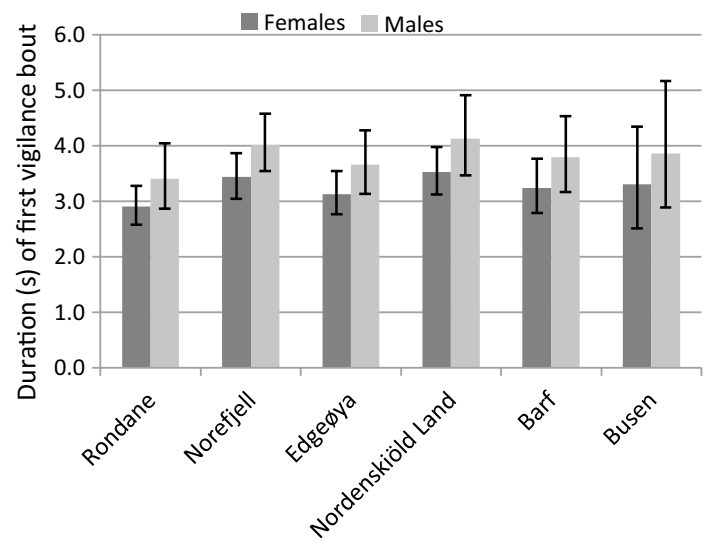

Fig. 3 Mean duration of first observed vigilance bout (s) (vigilance duration) in female and male reindeer in Rondane and Norefjell (southern Norway) and in Edgeøya and Nordenskiöld Land (Svalbard) in summer June to July in 2004 to 2006 and in Barf/Royal Bay and Busen (South Georgia) during summer in the southern Hemisphere (December to January) in 2012 and 2013

but decreased with increasing group size, as indicated in South Georgia (Fig. 2b).

Comparing 95\% confidence intervals in Fig. 4a vs. b, vigilance rate apparently provides a more accurate measure of vigilance in reindeer than duration.

\section{Discussion}

The way in which antipredator behaviour is modified depends on both heritable predisposition (Riechert and Hedrick 1990) as well as experience (Berger et al. 2001; Blumstein 2004). Using an island as a model, terrestrial prey become naïve to predation risk when predators have been absent for long periods (Byers 1997; Blumstein and Daniel 2005b). In accordance with expectations, domestic reindeer introduced to the predator free South Georgia showed a low vigilance response. However, and although we found a generally low vigilance response on South Georgia compared to reindeer on Svalbard and southern Norway, the Barf/Royal Bay reindeer were 3 times more vigilant than the Busen reindeer. Even though the introduction of reindeer to the two areas in South Georgia apparently originates from the same Norwegian domestic herd and hence same genetic stock during the 1920-ties (Lovatt 2007; Kilander 2014), only 10 and 7 animals, respectively, were transferred and the populations may have developed differently from "bottleneck" effects (Petersen et al. 2010). Animal density may also be an interacting factor, leaving the densely populated reindeer in Barf/Royal Bay more vigilant in search for food or space in competition with neighbouring animals (Kluever et al. 2008). A more likely explanation is adaptability to human presence (Colman et al. 2001; Reimers et al. 2010; Hansen and Aanes 2015). The Whaling station and associated human settlement (16-32 individuals during summer and winter) is located on Busen, and reindeer have over time adapted to the presence of human activities at Grytviken and of visiting scientists and tourist. The Barf/Royal Bay area are more remotely located and reindeer are rarely encountered by humans. During preparation prior to the extermination of the herds in 2012-2013, reindeer in both areas were exposed to extensive human activities that may have triggered a higher vigilance rate in the Barf/Royal Bay area than in Busen, where animals are more habituated to interacting humans. Such gradual habituation is widespread among animals and in this context, reported in Svalbard reindeer in $\mathrm{Ny}$ Ålesund (Hansen and Aanes 2015). As video recording of vigilance occurred in advance of extermination of the herds and from hidden positions in all areas, we find no support for vigilance differences being a result of recording activities.

"Predator free" Svalbard reindeer in Nordenskiöld Land exposed to frequent encounters with humans show relaxed vigilance behaviour with low vigilance rates and duration (Table 4; Fig. 4a, b). Surprisingly, Edgeøya displayed a higher vigilance rate comparable to wild reindeer in southern Norway subject to hunting and predation (Rondane). Polar bears are generally not regarded as predators on reindeer (Derocher et al. 2000). However, after the international harvest ban in 1973, the population of polar bears in the Svalbard archipelago has increased (Aars et al. 2009). In addition, the sea-ice cover in the arctic region during summer has decreased in recent years (Singarayer et al. 2006), resulting in more bears on land within several polar bear subpopulations (Schliebe et al. 2008; Rode et al. 2015) and 


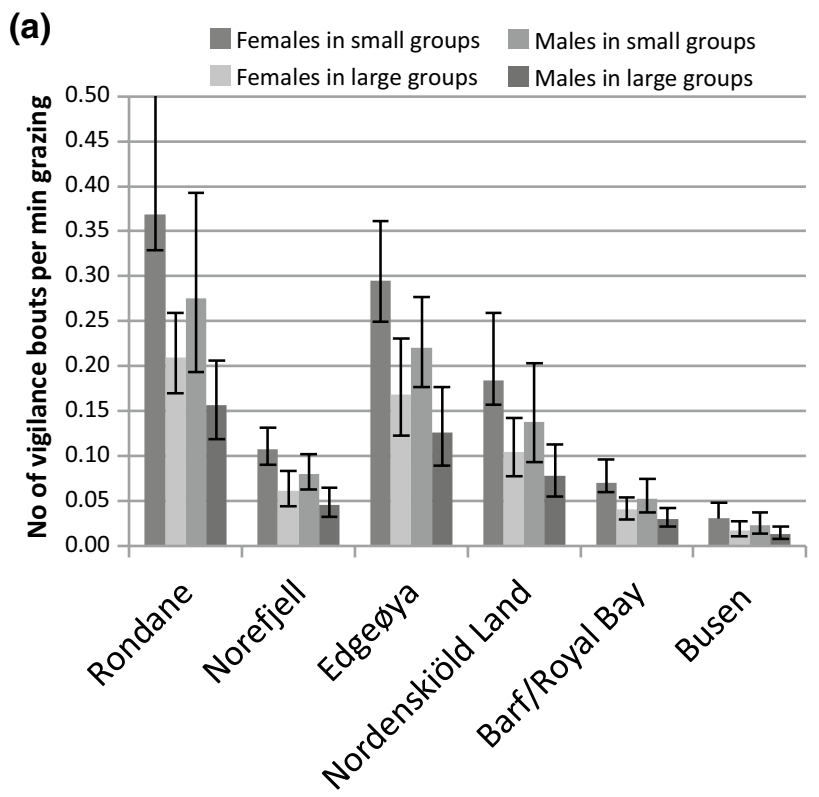

(b)

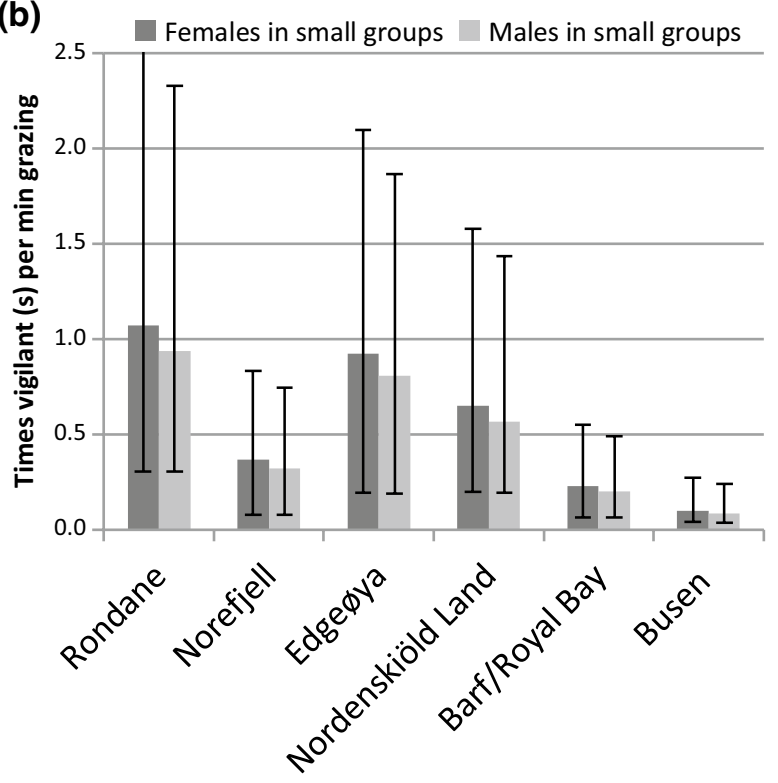

Fig. 4 a Predicted number of vigilance bouts $( \pm 2 S E$; approx. $95 \%$ $C I)$ per min (vigilance rate) with head above shoulder height $\leq 10 \mathrm{~s}$ while grazing in groups of reindeer in Rondane and Norefjell (southern Norway), Edgeøya and Nordenskiöld Land (Svalbard) in June/ July during 2003-2006 and Barf/Royal Bay and Busen (South Georgia) during summer in the southern Hemisphere (December-January) in 2012 and 2013. b Calculated total time spent vigilant (s) per min grazing ( $\pm 2 S E$; approx. $95 \% C I)$ in reindeer while grazing in groups of reindeer in Rondane and Norefjell (southern Norway), Edgeøya and Nordenskiöld Land (Svalbard) in June/July during 2003-2006 and Barf/Royal Bay and Busen (South Georgia) December-January in 2012 and 2013.during summer in the southern Hemisphere (December-January) in 2012 and 2013. Values are products of number of vigilance bouts per min grazing time $\times$ mean duration of first observed vigilance bout in the respective herd size and sex categories according to the equation below Reference level for categorical variables are in Tables 4 and 5.Vigilance duration (s) per min: grazing $=\exp (\ln ($ predicted frequency*$*($ predicted duration $)+\mathrm{c}(0,-2$, $2)^{*} \operatorname{sqrt}\left(\left(S E\right.\right.$ frequency^$^{\wedge} 2+S E$ duration $\left.\left.\left.^{\wedge} 2\right)\right)\right)$ thus, more frequent encounters between reindeer and polar bears. Edgeøya, being an important polar bear denning area (Aars et al. 2005), has a high density of polar bears during summer, greatly exceeding the density in Nordenskiöld Land (Derocher et al. 2000; IUCN 2010), probably resulting in a predator prey relationship between the two species (Reimers and Eftest $\varnothing 1$ 2012). This may explain increased vigilance among reindeer in the more densely polar bear populated Edgeøya (Reimers et al. 2011; Reimers and Eftestøl 2012; Iversen et al. 2013; Stempniewicz et al. 2014) and support that experience-dependant behaviour may be restored quickly upon individuals encountering predators (Griffin et al. 2000; Berger 2001).

Vigilance rates in Rondane vs. Norefjell, Nordenskiöld Land, and South Georgia were 3.5, 2.0 and 7.2 times higher, respectively. As Rondane wild reindeer on mainland Norway coexist and share 1000s of years with predators and hunters, their higher vigilance rates presumably reflects a behavioural adaptation to these threats. Reindeer in Busen in South Georgia and Svalbard reindeer in Nordenskiöld Land presumable reflect baseline vigilance among wild reindeer in the absence of or reduced threats from predators.

Vigilance rates for wild reindeer herds on mainland Norway (Reimers et al. 2012), caribou in West Greenland and Alaska (Bøving and Post 1997) and introduced domestic reindeer in South Georgia are surprisingly low regardless of absence or presence of predators or hunting compared to other herbivores (Underwood 1982; Burger and Gochfeld 1994; Toigo 1999; Wolff and Van Horn 2003; Benhaiem et al. 2008; Periquet et al. 2010). An explanation most probably combines two factors; the generally open, treeless alpine/Arctic environment inhabited by these Rangifer subspecies that allow warning time and the anatomy and physiology of the ungulate vision (Sjaastad et al. 2016). The most important function of the external ocular muscles in most four-footed animals is to keep the eyes horizontal when the position of the head changes. When Rangifer or other deer species graze, the eyes move to a horizontal position in the orbits and the animal then has a combined visual field for both eyes of about $360^{\circ}$ parallel to the ground, only limited by their legs. Therefore, grazing predominately in open habitats enables vigilance for Rangifer even when feeding, and hence, time used on "head lifting" vigilance can be reduced.

A commonly reported benefit of aggregation is seen when individuals reduce the time devoted to vigilance and increase time on foraging as group size increases (Lima and Dill 1990). Costly antipredator behaviour should not persist once there is no net benefit. And indeed, the traditional grouping behaviour that characterize Rangifer elsewhere is absent in Svalbard, where animals live individually or in small groups (Alendal and Byrkjedal 1976; Alendal et al. 1979). The lack of group behaviour in Svalbard reindeer as a response to the absence of predators and parasitizing 
insects facilitates energetic optimization and enables these animals to cope with this harsh environment (Reimers 1980; Reimers et al. 1982). It is generally assumed that gregariousness increases safety (Turner and Pitcher 1986; Rieucau and Martin 2008) and that reproductive status influence how animals reduce predation risk and that some individuals take advantage of the vigilance effort provided by others (Rieucau and Martin 2008). Correspondingly, there was a group size effect in our study as vigilance generally decreased with increasing group size. High vigilance rates will in most cases compromise feeding time as suggested by (Laundre et al. 2001), although vigilance is not necessarily mutually exclusive with processing food (chewing and swallowing) (Fortin et al. 2004). Future studies should test whether the low scan frequency and total scan duration found for reindeer in this study compromise or increase feeding efficiency, along with the costs of head-bobbing within complete energy budgets.

Vigilance rates were higher among females with calf at foot than among males. This is consistent with results reported for other wild ungulates (Lipetz and Bekoff 1982; Burger and Gochfeld 1994; Toigo 1999; Childress and Lung 2003; Wolff and Van Horn 2003; Rieucau and Martin 2008) and also for domesticated ungulates (Kluever et al. 2008). In South Georgia, we found a close relationship between vigilance rate and duration: confidence intervals indicated a significant difference in both traits (Fig. 2a, b). There was a corresponding relationship between rate and duration in an area comparison (Fig. 4a, b); significant differences in vigilance rate, yet broad confidence intervals and non-significant differences in duration. This suggests that small differences in duration of first vigilance bout (Fig. 3), combined with large differences in rate (Fig. 4a) mask the area differences in duration, as reflected in Fig. 4b. Selection seemingly favours vigilance rate rather than duration in response to predators or neighboring animals competing for the same grazing resources. Feed intake and survival should both benefit from increased vigilance rates. This indicates flexibility in rate, but not in duration, that appear to be much less variable. Furthermore, a vigilance rate 2 times higher in Rondane than in Norefjell-Reinsjøfjell, 1.3 and 3.5 times higher than in Svalbard and Edgeøya and Nordenskiöld Land, and 7 times higher than in South Georgia indicates a variation in vigilance rates. This is probably caused by an interaction amongst factors including environment, genetics and human interference as suggested by Reimers et al. (2012).

Amongst our study areas, vigilance rate varied considerably, while duration remained constant, supporting a hard-wired adaptation for vigilance duration in Rangifer that appears even less variable than grouping behaviour. A minimum amount of time allowing for focusing, recognition and registration of stimuli will likely set a lower limit for duration. Additional investigations are necessary into mechanisms driving such adaptations and the evolution of behavioural traits in wildlife. Reindeer provide the unique opportunity to study a species with both domestic and wild stock, along with differences in hunting, human interactions, predation and other key factors.

Acknowledgements We are indebted to personnel with the Office of the Commissioner Government House, Stanley, Falkland Islands for supplying data on reindeer vigilance from South Georgia prior to the extermination of the herds. In particular we I thank J. Lee with the Office of the Commissioner Gouvernment House, Stanley, Falkland Islands, A. Black, A. Wolfaardt and, A. Wilson for carrying out the field work. Financial support was provided from The Norwegian Science Foundation, Trygve Gotaas Fond, Direktoratet for Naturforvaltning, Stiftelsen Thomas Fearnley, Heddy og Nils Astrup. Sincere thanks to Roland Pape and two anonymous reviewers for most significat improvments to the manuscript.

Author contributions ER conceived and designed research. ER, SE and JEC conducted field work, analyzed the data and wrote the manuscript. All authors read and approved the manuscript.

Funding Open access funding provided by University of Oslo (incl Oslo University Hospital).

\section{Declarations}

Conflict of interest There are no conflict of interests related to our work.

Ethical approval We confirm that our work comply with the journal ethical standard.

Informed consent Informed consent was obtained from all individual participants included in the study.

Open Access This article is licensed under a Creative Commons Attribution 4.0 International License, which permits use, sharing, adaptation, distribution and reproduction in any medium or format, as long as you give appropriate credit to the original author(s) and the source, provide a link to the Creative Commons licence, and indicate if changes were made. The images or other third party material in this article are included in the article's Creative Commons licence, unless indicated otherwise in a credit line to the material. If material is not included in the article's Creative Commons licence and your intended use is not permitted by statutory regulation or exceeds the permitted use, you will need to obtain permission directly from the copyright holder. To view a copy of this licence, visit http://creativecommons.org/licenses/by/4.0/.

\section{References}

Aars J, Andersen M, Kovacs KM (2005) Isbjørn på Svalbard. Norsk polarinstitutt, Troms $\emptyset$

Aars J, Andersen M, Belikov S, Boltunov A, Buckland ST, Marques TA, Wiig Ø (2009) Estimating the Barents Sea polar bear subpopulation size. Mar Mamm Sci 25:35-52

Aastrup P (2000) Responses of West Greenland caribou to the approach of humans on foot. Polar Res 19:83-90 
Alendal E, Byrkjedal I (1976) Population size and reproduction of the reindeer (Rangifer tarandus platyrhynchus) on Nordenskiöld Land. Svalbard Nor Polarinst Årbok 1974:139-152

Alendal E, de Bie S, van Wieren SE (1979) Size and composition of the wild reindeer (Rangifer tarandus platyrhynchus) population in the Southeast Svalbard Nature Reserve. Holarct Ecol 2:101-107

Andersen R, Hustad H (2004) Villrein \& Samfunn. En veiledning til bevaring og bruk av Europas siste villreinfjell. Norsk institutt for naturforskning, Trondheim

Baskin LM (2005) Number of wild and domestic reindeer in Russia in the late 20th century. Rangifer 25:51-58

Benhaiem S et al (2008) Hunting increases vigilance levels in roe deer and modifies feeding site selection. Anim Behav 76:611-618. https://doi.org/10.1016/j.anbehav.2008.03.012

Berger J (2001) Recolonizing carnivores and naive prey: conservation lessons from Pleistocene extinctions. Science 291:1036-1039

Berger J (2007) Carnivore repatriation and holarctic prey: narrowing the deficit in ecological effectiveness. Conserv Biol 21:11051116. https://doi.org/10.1111/j.1523-1739.2007.00729.x

Berger J, Swenson JE, Persson IL (2001) Recolonizing carnivores and naive prey: conservation lessons from Pleistocene extinctions. Science 291:1036-1039

Blumstein DT (2004) A test of the multi-predator hypothesis: Rapid loss of antipredator behavior after 130 years of isolation. Ethology 110:919-934

Blumstein DT (2006) The multipredator hypothesis and the evolutionary persistence of antipredator behavior. Ethology 112:209217. https://doi.org/10.1111/j.1439-0310.2006.01209.x

Blumstein DT, Daniel JC (2005a) The loss of anti-predator behaviour following isolation on islands. Proc R Soc Lond Ser B-Biol Sci 272:1663-1668

Blumstein DT, Daniel JC (2005b) The loss of anti-predator behaviour following isolation on islands. Proc R Soc Biol Sci Ser B 272:1663-1668

Bøving PS, Post E (1997) Vigilance and foraging behaviour of female caribou in relation to predation risk. Rangifer 17:55-63

Brown GE, Chivers DP, Smith RJF (1997) Differential learning rates of chemical versus visual cues of a northern pike by fathead minnows in a natural habitat. Environ Biol Fishes 49:89-96

Burger J, Gochfeld M (1994) Vigilance in African Mammals-differnces among mothers, other females and males. Behaviour 131:153-169

Byers JA (1997) American pronghorn: social adaptations and the ghosts of predators past. Chicago Univiversity Press, Chicago

Childress MJ, Lung MA (2003) Predation risk, gender and the group size effect: does elk vigilance depend upon the behaviour of conspecifics? Anim Behav 66:389-398. https://doi.org/10.1006/ anbe. 2003.2217

Clutton-Brock J (1987) A natural history of domesticated animals. Cambridge University Press, London

Colman JE, Jacobsen BW, Reimers E (2001) Summer response distances of Svalbard reindeer Rangifer tarandus platyrhynchus to provocation by humans on foot. Wildl Biol 7:275-283

Colman JE et al (2012) Behavioral Interference Between Sympatric Reindeer and Domesticated Sheep in Norway Rangel. Ecol Manag 65:299-308

Coss RG (1999) Effects of relaxed natural selection on the evolution of behavior. In: Foster SA, Endler JA (eds) Geographic variation in behavior: perspectives on evolutionary mechanisms. Oxford University Press, Oxford, pp 180-208

Derocher AE, Wiig O, Bangjord G (2000) Predation of Svalbard reindeer by polar bears. Polar Biol 23:675-678

Elgar MA (1989) Predator vigilance and group-size in mammals and birds-acritical review of the empirical-evidence. Biol Rev (Camb) 64:13-33
Fortin D, Boyce MS, Merrill EH (2004) Multi-tasking by mammalian herbivores: overlapping processes during foraging. Ecology 85:2312-2322

Frid A (1997) Vigilance by female Dall's sheep: interactions between predation risk factors. Anim Behav 53:799-808

Griffin AS, Blumstein DT, Evans C (2000) Training captive-bred or translocated animals to avoid predators. Conserv Biol 14:1317-1326

Hamilton WD (1971) Geometry for the selfish herd. J Theor Biol 31:295-311

Hansen BB, Aanes R (2015) Habituation to humans in a predatorfree wild ungulate. Polar Biol 38:145-151. https://doi.org/10. 1007/s00300-014-1572-0

Hovelsrud KR (2009) Isbjørn som dreper reinsdyr (In Norwegian) Svalbardposten

IUCN (2010) Summary of polar bear population status per 2010. In: Edited by Report from the IUCN Polar Bear Specialist Group. IUCN

Iversen M, Aars J, Haug T, Alsos IG, Lydersen C, Bachmann L, Kovacs KM (2013) The diet of polar bears (Ursus maritimus) from Svalbard, Norway, inferred from scat analysis. Polar Biol 36:561-571

Jensen P (2006) Domestication-from behaviour to genes and back again. Appl Anim Behav Sci 97:3-15. https://doi.org/10.1016/j. applanim.2005.11.015

Jensen P (2014) Behavior genetics and the domestication of animals. Annu Rev Animal Biosci 2:85-104. https://doi.org/10.1146/annur ev-animal-022513-114135

Kilander CE (2014) Fjerning av reinsdyr på Sør-Georgia - nok et avsluttet kapittel i norsk hvalfangsthistorie. In: Barr S, Gjertz J, Mehlum F (eds) Polarboken, vol 13-14. Norsk Polarklubb, Oslo, pp 5-23

Kluever BM, Breck SW, Howery LD, Krausman PR, Bergman DL (2008) Vigilance in cattle: the influence of predation, social interactions, and environmental factors Rangel. Ecol Manag 61:321328. https://doi.org/10.2111/07-087.1

Lahti DC et al (2009) Relaxed selection in the wild. Trends Ecol Evol 24:487-496. https://doi.org/10.1016/j.tree.2009.03.010

Laundre JW, Hernandez L, Altendorf KB (2001) Wolves, elk, and bison: reestablishing the "landscape of fear" in Yellowstone National Park. USA Can J Zool 79:1401-1409

Leader Williams N (1988) Reindeer on South Georgia: the ecology of an introduced population. Cambridge University Press, Cambridge

Leader Williams N, Payne MR (1980) Status of Rangifer on South Georgia. In: Reimers E, Skjenneberg S, Gaare E (eds) Proceeding of the 2nd International Reindeer/Caribou Symposium, Røros, Norway 1979. Direktoratet for vilt og ferskvannsfisk, Trondheim, pp 786-789

Lima SL (1995) Back to the basics of anti-predatory vigilance: the group-size effect. Anim Behav 49:11-20

Lima SL, Dill LM (1990) Behavioral decisions made under the risk of predation: a review and prospectus. Can J Zool 68:619-640

Lindsey DC (1973) Effects of reindeer on plant communities in the Royal Bay area of South Georgia. Br Antarct Surv Bull 35:101-109

Lipetz VE, Bekoff M (1982) Group size and vigilance in pronghorns Antilocapra-americana. Z Tierpsychol 58:203-216

Lovatt FM (2007) A study of the impact of population bottlenecks on the genetics and morphology of reindeer (Rangifer tarandus tarandus) on the island of South Georgia. Durham University, Durham

Matthiopoulos J (2003) The use of space by animals as a function of accessibility and preference. Ecol Modell 159:239-268

McIntosh E, Walton DWH (2000) Environmental management plan for South Georgia, Stanley. Government of South Georgia and the South Sandwich Islands, Stanley 
Mirov NT (1945) Notes on the domestication of reindeer. Am Anthropol 47:393-408. https://doi.org/10.1525/aa.1945.47.3.02a00030

Mooring MS, Fitzpatrick TA, Nishihira TT, Reisig DD (2004) Vigilance, predation risk, and the allee effect in desert bighorn sheep. J Wildl Manag 68:519-532

Olstad O (1930) Rats and reindeer in the Antarctic, vol 4. Det norske vitenskabsakademi, Oslo

Periquet S, Valeix M, Loveridge AJ, Madzikanda H, Macdonald DW, Fritz H (2010) Individual vigilance of African herbivores while drinking: the role of immediate predation risk and context. Anim Behav 79:665-671. https://doi.org/10.1016/j.anbehav.2009.12.016

Petersen SD, Manseau M, Wilson PJ (2010) Bottlenecks, isolation, and life at the northern range limit: Peary caribou on Ellesmere Island, Canada. J Mammal 91:698-711. https://doi.org/10.1644/ 09-mamm-a-231.1

Price EO (1984) Behavioral aspects of animal domestication. Q Rev Biol 59:1-32

Price EO (1997) Behavioural genetics and the process of animal domestication. In: Grandin T (ed) Genetics and the behaviour of domestic animals. Academic Press, Cambridge, pp 31-65

Reimers E (1980) Activity pattern; the major determinant for growth and fattening in Rangifer? In: Reimers E, Gaare E, Skjenneberg S (eds) Proc 2nd Int Reindeer/Caribou Symp, Røros, Norway 1979. Direktoratet for Vilt og Ferskvannsfisk, Trondheim, pp 466-474

Reimers E, Eftest $\varnothing 1$ S (2012) Response behaviours of Svalbard reindeer towards humans and humans disguised as polar bears on Edgeøya. Arct Antarct Alp Res 44:483-489

Reimers E, Klein DR (1979) Reindeer and Caribou. Nature 282:558-559

Reimers E, Ringberg T, Sørumgard R (1982) Body composition of Svalbard reindeer. Can J Zool 60:1812-1821

Reimers E, Loe LE, Eftest $\varnothing 1$ S, Colman JE, Dahle B (2009) Effects of hunting on response behaviors of wild reindeer. J Wildl Manag 73:844-851. https://doi.org/10.2193/2008-133

Reimers E, Røed KH, Flaget Ø, Lurås E (2010) Habituation responses in wild reindeer exposed to recreational activities. Rangifer 30:45-59

Reimers E, Lund S, Ergon T (2011) Vigilance and fright behaviour in the insular Svalbard reindeer. Can J Zool 89:753-764

Reimers E, Røed KH, Colman JE (2012) Persistence of vigilance and flight response behaviour in wild reindeer with varying domestic ancestry. J Evol Biol 25:1543-1554

Riechert SE, Hedrick AV (1990) Levels of predation and genetically based anti-predator behaviour in the spider, Agenolopsisaperta. Anim Behav 40:679-687

Rieucau G, Martin JGA (2008) Many eyes or many ewes: vigilance tactics in female bighorn sheep Ovis canadensis vary according to reproductive status. Oikos 117:501-506. https://doi.org/10.1111/j. 2007.0030-1299.16274.x

Rode KD, Wilson RR, Regehr EV, Martin MS, Douglas DC, Olson J (2015) Increased land use by Chukchi Sea polar bears in relation to changing sea ice conditions. PLoS ONE. https://doi.org/10. 1371/journal.pone.0142213

Røed KH (1985) Genetic-variability in Norwegian Semi-Domestic Reindeer (Rangifer-Tarandus L.). Hereditas 102:177-184

Røed KH (1987) Transferrin variation and body size in Reindeer, Rangifer-Tarandus L. Hereditas 106:67-71

Røed KH, Flagstad $\varnothing$, Nieminen M, Holand $\varnothing$, Dwyer MJ, Rov N Vila C (2008) Genetic analyses reveal independent domestication origins of Eurasian reindeer. Proc Royal Soc London Ser B Biol Sci 275:1849-1855. https://doi.org/10.1098/rspb.2008.0332

Sandal T (2008) Blant rein og bjørn (In Norwegian) Svalbardposten

Schliebe S, Rode KD, Gleason JS, Wilder J, Proffitt K, Evans TJ, Miller S (2008) Effects of sea ice extent and food availability on spatial and temporal distribution of polar bears during the fall open-water period in the Southern Beaufort Sea. Polar Biol 31:999-1010

Singarayer JS, Bamber JL, Valdes PJ (2006) Twenty-first-century climate impacts from a declining Arctic Sea ice cover. J Clim 19:1109-1125

Sjaastad ØV, Sand O, Haave K (2016) Physiology of domestic animals. Scandinavian Veterinary Press, Oslo

Stankowich T, Coss RG (2007) The re-emergence of felid camouflage with the decay of predator recognition in deer under relaxed selection. Proc R Soc Lond Ser B-Biol Sci 274:175-182

Stempniewicz L, Kidawa D, Barcikowski M, Iliszko L (2014) Unusual hunting and feeding behaviour of polar bears on Spitsbergen. Polar Rec 50:216-219

Toigo C (1999) Vigilance behavior in lactating female Alpine ibex. Can J Zool 77:1060-1063

Turner GF, Pitcher TJ (1986) Attack abatement: a model for group protection by combined avoidance and dilution. Am Nat 128:228-240

Tyler NJC (1986) Reinen i Adventdalen. In: Øritsland NA (ed) Svalbardreinen og dens livsgrunnlag (In Norwegian). Universitetsforlaget, Oslo, pp 143-159

Tyler NJC, Øritsland NA (1989) Why dont Svalbard Reindeer migrate. Holarct Ecol 12:369-376

Underwood R (1982) Vigilance behaviour in grazing african antelopes. Behaviour 79:81-107

Van der Knaap WO (1986) On the presence of reindeer (Rangifer tarandus L.) on Edgeøya, Spitzbergen in the period 3800-5000 BP. Circumpolar J 2:3-10

Wolff JO, Van Horn T (2003) Vigilance and foraging patterns of American elk during the rut in habitats with and without predators. Can J Zool 81:266-271

Publisher's Note Springer Nature remains neutral with regard to jurisdictional claims in published maps and institutional affiliations. 